Journal of Economic, Business and Accounting (COSTING)

Volume 1 Nomor 2, Juni 2018

e-ISSN : 2597-5234

https://doi.org/10.31539/costing.v1i2.248

\title{
PENGARUH MUTASI DAN PELATIHAN KERJA TERHADAP SEMANGAT KERJA DAN DAMPAKNYA PADA PRESTASI KERJA PEGAWAI PADA KANTOR KEMENTERIAN AGAMA KOTA CILEGON
}

\section{THE EFFECT OF MUTATION AND JOB TRAINING ON JOB SPIRIT AND ITS IMPACT ON EMPLOYEE ACHIEVEMENT AT MINISTRY OF RELIGION OFFICE, CILEGON}

\author{
Putri Wahyu Novika \\ Sekolah Tinggi Ilmu Ekonomi Galileo \\ putrikasim11@gmail.com
}

\begin{abstract}
Job achievement is very important for an organization or company to achieve its goals. The expected goal can be achieved through this research is to see the Effect of Mutation and Job Training on Job spirit And Its Impact at Ministry of Religion Office Of, Cilegon. The sample in this research were 100 employees of Cilegon city ministry office of total population of 339 employees. Data analysis technique used is path analysis. The results show that there is a significant influence between mutation, job training system and job spirit partially. Job mutations (X1) and job training (X2) affect job spirit (Z) by $85 \%$, and the rest are influenced by other variables. Furthermore there is also significant influence between work mutation, job training and work morale on job performance partially, where the influence of 78,5\%, and the rest influenced by other variables
\end{abstract}

Keywords: mutation, job training, morale, employee achievement

\begin{abstract}
ABSTRAK
Prestasi kerja sangat penting bagi sebuah organisasi atau perusahaan untuk mencapai tujuannya. Tujuan yang diharapkan dapat dicapai melalui penelitian ini adalah untuk melihat Pengaruh Mutasi Dan Pelatihan Kerja Terhadap Semangat Kerja Dan Dampaknya Pada Prestasi Kerja Pegawai Pada Kantor Kementerian Agama Kota Cilegon. Sampel dalam penelitian ini adalah 100 orang karyawan kantor kementrian agama kota Cilegon dari total populasi sebanyak 339 karyawan. Teknik analisa data yang digunakan adalah analisis jalur. Hasil penelitian menunjukkan bahwa secara parsial terdapat pengaruh signifikan antara mutasi, sistem pelatihan kerja dan semangat kerja. Mutasi kerja (X1) dan pelatihan kerja (X2) mempengaruhi variabel semangat kerja (Z) sebesar $85 \%$, dan sisanya dipengaruhi oleh variabel lain-lain. Selanjutnya juga terdapat pengaruh signifikan antara mutasi kerja, pelatihan kerja dan semangat kerja terhadap prestasi kerja, dimana pengaruhnya sebesar 78,5\%, dan sisanya dipengaruhi oleh variabel - variabel lain
\end{abstract}

Kata Kunci: mutasi, pelatihan kerja, semangat kerja, prestasi kerja 


\section{PENDAHULUAN}

Prestasi kerja sangat penting bagi sebuah organisasi atau perusahaan untuk mencapai tujuannya. Dalam konteks pengembangan sumber daya manusia prestasi kerja seorang karyawan dalam sebuah organisasi sangat dibutuhkan untuk mencapai prestasi kerja bagi karyawan itu sendiri dan juga untuk keberhasilan perusahaan. Prestasi kerja merupakan suatu fungsi dari motivasi dan kemampuan untuk menyelesaikan tugas atau pekerjaan. Seseorang sepatutnya memiliki derajat kesediaan dan tingkat kemampuan tertentu. Kesediaan dan keterampilan seseorang tidaklah cukup efektif untuk mengerjakan sesuatu tanpa pemahaman yang jelas tentang apa yang akan dikerjakan dan bagaimana mengerjakan. Prestasi kerja merupakan perilaku nyata yang ditampilkan setiap orang sebagai prestasi kerja yang dihasilkan oleh pegawai sesuai dengan perannya dalam instansi.Prestasi kerja karyawan merupakan suatu hal yang sangat penting dalam upaya instansi untuk mencapai tujuan.

Tujuan tersebut baru dapat dicapai apabila ada upaya peningkatan pemanfaatan sumber daya manusia dan sumber daya bukan manusia, serta pelaksanaan pembangunan disegala bidang, terencana, terarah, bertahap dan berkesinambungan. Salah satu bidang tersebut adalah pembangunan manusia seutuhnya. Dalam hal ini keberhasilan dari tujuansetiap organisasi tergantung pada aspek manusianya yakni sebagai pemimpin, pelaksana dan pengelola sumber daya yang ada. Seperti halnya di sebuah perusahaan dalam instansi pemerintahanpun sumber daya manusia sangat dominan menentukan suatu keberhasilan dari pada tujuan instansi tersebut. Dalam hal ini sumber daya pada instansi pemerintah adalah Pegawai Negeri Sipil (PNS).

Pegawai Negeri Sipil (PNS) yang merupakan aparatur negara yang menyelenggarakan pemerintahan dalam melaksanakan pembangunan nasional merupakan tulang punggung pemerintah. Kelancaran penyelenggaraan pemerintahan dan pelaksanaan pembangunan nasional terutama tergantung pada kesempurnaan aparatur negara baik ditingkat pusat maupun ditingkat daerah. Dalam ragka mencapai tujuan nasional sebagaimana dikemukakan di atas, diperlukan adanya pegawai negeri sipil yang penuh kesediaan dan ketaatan kepada Pancasila, Undang-Undang Dasar 1945, negara dan pemerintah serta bersatu padu, bermental baik, berwibawa, kuat berdaya guna, bersih, berkualitas tinggi dan sadar akan tanggung jawabnya sebagai unsur aparatur Negara, abdi Negara dan abdi masyarakat.

Dengan adanya Peraturan Pemerintah Nomor 43 Tahun 1999 tentang pokok-pokok kepegawaian, dan tentang wewenang pengangkatan, pemindahan dan pemberhentian pegawai negeri sipil diatur di dalam Peraturan Pemerintah Nomor 96 Tahun 2000. Kedua Peraturan perundangundangan tersebut merupakan pedoman pelaksanaan mutasi kepegawaian di setiap instansi pemerintah umum dan untuk mewujudkan Pegawai Negeri Sipil (PNS) yang sempurna sebagaimana dimaksudkan di atas, maka pegawai negeri sipil perlu dibina dengan sebaik-baiknya dan diadakan pengembangan.

Tujuan pembinaan dan pengembangan (Fathoni, 2006:194) tersebut diharapkan agar setiap pegawai yang ada dalam organisasi yang bersangkutan dapat memberikan prestasi kerja yang sebaik-baiknya sehingga benarbenar dapat berfungsi sebagai penghasil kerja yang tepat guna sesuaj dengan sasaran organisasi yang hendak dicapai, terwujudnya hubungan yang serasi antara atasan dan bawahan serta terwujudnya pegawai-pegawai yang setia dan taat kepada Pancasila, Undang-Undang Dasar 1945, Negara dan Pemerintah, sehingga pegawai hanya mengabdi kepada kepentingan negara dan masyarakat, demi 
terwujudnya aparatur yang bersih dan berwibawa.

Beberapa bentuk dari pengembangan terhadap pegawai negeri sipil adalah mutasi dan pelatihan sebagai penjelmaan/perwujudan dari dianamika organisasi yang dijadikan sebagai salah satu cara untuk mencapai tujuan organisasi.

Mutasi tidak terlepas dari alasan untuk mengurangi rasa bosan pegawai kepada pekerjaan serta meningkatkan motivasi dan semangat kerja pegawai, selain itu untuk memenuhi keinginan pegawai sesuai dengan minat dan bidang tugasnya masing-masing dimana dalam kegiatan pelaksanaan mutasi kerja sering disalah tafsirkan orang yaitu sebagai hukuman jabatan atau didasarkan atas hubungan baik antara atasan dengan bawahan serta meningkatkan prestasi kerja pegawai itu sendiri.

Dalam pelaksanaan mutasi harus benar-benar berdasarkan penilaian yang objektif dan didasarkan atas indeks prestasi yang dicapai oleh pegawai mengingat sistem pemberian mutasi dimaksudkan untuk memberikan peluang bagi para pegawai negeri sipil untuk mengembangkan potensi yang dimilikinya. Sedangkan Pelatihan dilakukan guna mencitakan Pegawai yang berkualitas disamping bukan hanya proses perekrutan pegawai yang tepat dan mutasi kerja, menyelenggarakan proses pelatihan juga sebagai bahan peningkatan produktifitas serta prestasi bagi Pegawai.

Meskipun proses pelatihan tenaga kerja dan mutasi memerlukan biaya yang tidak sedikit, tetapi proses ini harus tetap dilaksanakan karena hal tersebut mempunyai manfaat yang sangat besar, baik bagi perusahaan maupun bagi pegawai dan bagi Organisasi situ sendiri. Manfaat bagi Organisasi antara lain adalah Mempunyai pegawai yang produktif dan siap melaksanakan pekerjaannya serta memiliki beragam kemampuan sehingga dengan adanya tenaga kerja yang demikian
Suatu Organisasi dapat mencapai tujuannya dengan lebih mudah.

Manfaat bagi Pegawai itu sendiri adalah mereka dapat mengembangkan sikap, perilaku, keterampilan, pengetahuan tentang pekerjaannya dan dapat memberikan kontribusi yang baik serta dapat memberikan kemampuannya terhadap pegawai lain di dalam organisasi. Hal ini juga akan meningkatkan produktivitas kerja para pegawai yang bersangkutan, sehingga dapat lebih menunjang tercapainya tujuan perusahaan secara efisien dan efektif.

Demikian sebaliknya Semangat kerja pegawai juga dapat menurun apabila pihak atasan tidak memperhatikan kepentingan para bawahan. Hal ini akan menurunkan semangat kerja para pegawai. Indikator dari turunnya semangat kerja antara lain rendahnya produktivitas, tingkat absensi pegawai tinggi, gaji rendah, dan lain-lain. Dengan demikian pastilah akan mempengaruhi semangat kerja pegawai dalam suatu organisasi.

Hal inilah yang mendorong untuk meneliti masalah mutasi dan pelatihan yang dikaitkan dengan semangat kerja pegawai serta dampaknya terhadap prestasi kerja pegawai negeri sipil di Kantor Kementrian Agama Kota Cilegon dengan pemikiran bagaimana upaya untuk menumbuhkan semangat kerja dikalangan pegawai sehingga semangat kerja pegawai dapat meningkat produktifitas, khususnya pegawai pada Kantor Kementrian Agama Kota Cilegon Berdasarkan uraian singkat di atas, penulis tertarik untuk meneliti dan membahas hal ini menjadi sebuah objek penelitian, dengan judul "Pengaruh Mutasi dan Pelatihan Kerja Terhadap Semangat Kerja dan Dampaknya PadaPrestasi Kerja Pegawai Pada Kantor Kementerian Agama Kota Cilegon".

\section{METODE PENELITIAN}

Metode penelitian yang digunakan adalah metode penelitian kuesioner yang dipilih untuk mengumpulkan data, karena kuesioner atau angket mempunyai banyak 
kebaikan sebagai instrumen pengumpul data. Pelaksanaan penelitian kuesioner dilakukan dengan mengajukan beberapa pertanyaan kepada pegawai Pada Kantor Kementerian Agama Kota Cilegon.

Jika dibuatkan desain penelitian maka akan terbentuk pola Konstelasi penelitian sebagai berikut :

Gambar 3.1

\section{Konstelasi Penelitian}

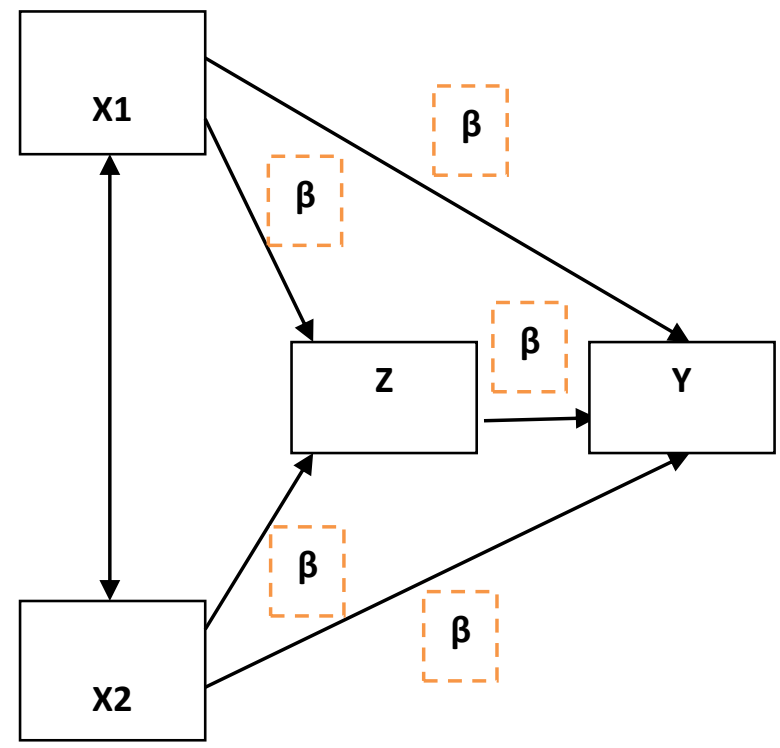

Keterangan :

$\mathrm{Y}=$ Prestasi Kerja Pegawai

$\mathrm{Z}=$ Semangat Kerja

$\mathrm{X} 1=$ Mutasi Kerja

$\mathrm{X} 2$ = Pelatihan Kerja

\section{Populasi dan Sampel}

Jumlah sampel yang digunakan minimal adalah 100 responden dari populasi pegawai kementrian agama kota cilegon sebanyak 339 pegawai, Pengambilan jumlah sampel berdasarkan teknik perhitungan Slovin Dimana :

$\mathrm{n}=$ jumlah sampel minimal

$\mathrm{N}=$ jumlah populasi

e $=$ standard error/ persentase kelonggaran ketelitian karena kesalahan pengambilan (10\%).

Dari rumus tersebut dapat diketahui bahwa jumlah sampel yang akan diteliti adalah sebanyak :

$$
\begin{aligned}
& \mathrm{n}=\frac{}{1+\mathrm{Ne}^{2}} \\
& \mathrm{n}=\frac{\mathrm{N}}{1+\mathrm{N}(0.1)^{2}} \\
& \mathrm{n}=\frac{339}{1+339(0.1)^{2}} \\
& \mathrm{n}=99.7
\end{aligned}
$$

Teknik pengambilan sampel dalam penelitian ini adalah esedensial sampling, dimana dalam teknik ini hanya karyawankaryawan yang sesuai dengan pertimbangan dan syarat khusus saja yang bisa dijadikan sampel, dengan begitu akan diperoleh data dari karyawan yang benarbenar mempunyai pengetahuan yang mendalam mengenai instansi.

\section{Variabel Penelitian}

Agar data yang dikumpulkan memiliki kualitas yang tinggi, untuk menguji ketepatan hipotesis yang disusun, maka kuesioner harus di uji kualitas dan reabilitasnya. Suatu kuesioner dikatakan valid (sah ) jika pernyataan pada kuesioner mampu untuk mengungkapkan sesuatu yang akan diukur oleh kuesioner tersebut. Sedangkan kuesioner dinyatakan reliabel (andal) apabila jawaban responden terhadap pernyataan adalah konsisten atau stabil dari waktu kewaktu. (Sugiyono 2008: 172)

\section{Variabel Prestasi Kerja Pegawai}

Konsep dari variabel ini adalah prestasi kerja prestasi kerja merupakan pencapaian hasil yang tinggi oleh karyawan yang didasari oleh sikap disiplin, inisiatif serta motivasi yang tinggi dalam melaksanakan suatu pekerjaan sehingga dapat mencapai tujuan yang diharapkan. Dimensi dari prestasi kerja pegawai adalah :

a. Kualitas Kerja, dengan indikator ( imbal jasa, kualitas pengawasan, beban kerja dan lingkungan kerja )

b. Potensi Diri, dengan Indikator ( penilaian kinerja, minat pegawai, senioritas, ketrampilan pekerjaan, sifat kepribadian pegawai ) 


\section{Variabel Semangat Kerja}

Semangat kerja dapat diartikan sebagai semacam pernyataan ringkas dari kekuatan-kekuatan psikologis yang beraneka ragam yang menekan sehubungan dengan pekerjaan mereka. Semangat kerja dapat diartikan juga sebagai suatu iklim atau suasana kerja yang terdapat di dalam suatu organisasi yang menunjukkan rasa kegairahan di dalam melaksanakan pekerjaan dan mendorong mereka untuk bekerja secara lebih baik dan lebih produktif. Dimensi dari semangat kerja adalah :

1. Bersifat materi dengan indikator ( gaji, pemberian insentif dan fasilitas kerja)

2. Bersifat non materi dengan indikator ( loyalitas, individu pegawai dan harga diri pegawai)

\section{Variabel Mutasi}

Dalam konsep ini dapat diartikan bahwa mutasi adalah perpindahan karyawan dari suatu pekerjaan kepekerjaan lain yang dianggap sederajat mempunyai tujuan terutama agar tugas pekerjaan dapat dilaksanakan dengan lebih baik. Salah satu dasar untuk melaksanakan rotasi jabatan atau mutasi kerja adalah kemampuan kerja dari karyawan yang bersangkutan. Dimensi dari mutasi itu sendiri adalah :

1. Jabatan dan Pekerjaan dengan Indikator (Daftar urut kepangkatan, kekosongan posisi jabatan, serta keahlian )

2. Pengembangan diri dengan Indikator (Pengalaman, Kepercayaan, Kesetiaan, Perhatian, serta Kemampuan pegawai ).

\section{Variabel Pelatihan Kerja}

Dalam konsep ini dapat diartikan bahwa pelatihan adalah suatu upaya dalam memberikan pengetahuan, pelatihan lebih merujuk pada pengembangan keterampilan bekerja (vocational) yang dapat digunakan dengan segera, sedangkan pendidikan memberikan pengetahuan tentang subyek tertentu, tetapi sifatnya lebih umum, terstruktur untuk jangka panjang. peningkatan kemampuan dan pengalaman juga metode dalam pemecahan masalah sehingga ilmu yang didapatkan berguna dan bisa disosialisasikan untuk mencapai tujuan bersama.

Dimensi dari pelatihan adalah:

a. Peserta pelatihan dengan Indikator (tanggapan, respon, peningkatan kinerja)

b. Instruktur Pelatihan dengan Indikator (metode pelatihan, cara penyampaian materi dan komunikasi)

c. Sarana dan prasarana pelatihan dengan Indikator ( kenyamanan, fasilitas pelatihan )

\section{Metode Analisa Data}

\section{1) Uji Uji Validitas}

Dalam uji validitas (ketepatan) penulis akan mengukur validitas internal consistency dengan analisis item menurut Masrun yaitu item yang mempunyai korelasi positif dengan kriterium (skor total), dan jika hasil korelasinya tinggi artinya skor tersebut memiliki validitas yang tinggi. Setelah didapat hasil perhitungan maka penulis akan membandingkan antara nilai tabel $r$ product moment. Jika $r$ hitung lebih besar dari $\mathrm{r}$ tabel maka butir kuisioner tabel tersebut dinyatakan valid.

Rumus perhitungan yang digunakan adalah sebagai berikut :

$$
\boldsymbol{r} x y=\frac{n \sum x y-\left(\sum x\right)\left(\sum y\right)}{\sqrt{\left.\left(\left(n \sum x 2\right)-\left(\sum x\right)^{2}\right)\left(\left(n \sum y 2\right)-\left(\sum y\right)^{2}\right)\right)}}
$$

Besarnya $r$ tiap butir pertanyaan dapat dilihat dari hasil analisis SPSS pada kolom corrected items total correlation. Kriteria uji validitas secara singkat apabila nilai $r$ hitung $>r$ tabel. Jika korelasi $r$ hitung lebih besar daripada $r$ tabel maka butir pertanyaan tersebut dikategorikan valid (Santoso, 2000).

\section{2) Uji Reliabilitas}

Uji reliabilitas dimana uji ini untuk menunjukkan sejauh mana suatu instrumen dapat memberikan hasil 
pengukuran yang konsisten, apabila pengukuran dilakukan secara berulangulang. Dalam pengujian ini kita hanya menggunakan data atau butir-butir pertanyaan yang valid. Jika Cronbach Alpha > 0,6 maka reliabilitas pertanyaan bisa diterima (Setiaji, 204). Data dilakukan dengan pengujian realibilitas (konsistensi) dilakukan dengan internal consistency yaitu dengan menggunakan teknik Koefisien Alpha Cronbach dan Analisis Varian Hoyt (ANOVA). berikut :

Rumus yang dipergunakan sebagai

$$
=\frac{k}{k-1}\left\lfloor 1-\frac{\sum_{\sigma i} 2}{\sigma t^{2}}\right\rfloor
$$

\section{3) Persamaan Regresi}

Pengujian dan pembuatan persamaan ini guna mengetahui atau meramalkan suatu proses secara sistematis tentang apa yang bisa atau dapat terjadi di masa sekarang yang didasarkan dari penggunaan data masa lalu. Adapun persamaan umum berdasarkan pada gambar 3.2 maka didapat persamaan regresi sebagai berikut :

\section{Persamaan Uji Regresi 1 dan 2}

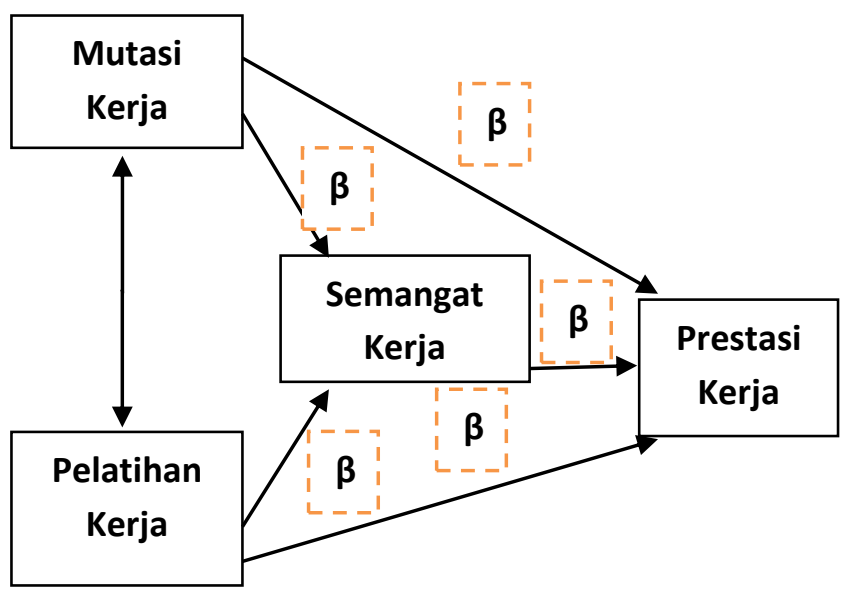

\section{Persamaaan Regresi 1}

$$
\hat{\mathrm{Y}}=\beta_{\mathrm{o}}+\beta_{1} \mathrm{x}_{1}+\beta_{2 \mathrm{X} 2}
$$

Dengan :
$\hat{Y}=$ variabel dependen yang dapat diproyeksikan

$\beta o=$ konstanta

$\beta_{1} \mathrm{X}_{1}$ dan $\beta_{2} \mathrm{x}_{2}=$ nilai koefisien

$\mathrm{X}=$ variabel independen

\section{Persamaan Regresi 2}

$$
Z=\alpha_{0}+\alpha_{1} X_{1}+\alpha_{2} X_{2}+\alpha_{3} Y
$$

$\mathrm{Z}=$ variabel dependen yang dapat diproyeksikan

$\alpha_{\mathrm{o}}=$ konstanta

$\alpha_{1} X_{1}+\alpha_{2} X_{2}+\alpha_{3} Y=$ nilai koefisien

$\mathrm{X}$ dan $\mathrm{Y}=$ variabel independen

\section{4) Uji Asumsi Klasik}

Kepastian bahwa model yang dapat dietimasi guna memenuhi asumsi klasik dengan tujuan melihat apakah asumsiasumsi yang mendasari formula OLS (Ordinary Least Square) tes terpenuhi, maka harus dipenuhi syarat BLUE (Best Linier Unbiased Estiamer) yaitu :

\section{Uji Normalitas}

Uji normalitas dilakukan guna menguji apakah model regresi variabel independent dan variabel dependent keduanya mempunyai distribusi normal atau tidak (Gozali, 2001). Asumsinya adalah jika variabel pengganggu berdistribusi normal, mka variabel yng diteliti juga berdistribusi normal, sehingga e perlu dilakukan pengujian normalitasnya. Dalam hal ini yang dipakai guna melakukan uji normalitas adalah Uji normalitas Kolmogorov Smirnov dan dinyatakan normal apabila mempunyai signifikansi diatas 0,05 .

\section{Uji Linearitas}

Dalam uji linearitas ini dimaksudkan untuk mengetahui hubungan korelasi khususnya korelasi produk moment termasuk didalamnya regresi. 
Pengambilan keputusannya adalah sebagai berikut :

a. Jika baris deviation from linearity baris ini tidak signifikan, maka dapat dikatakan bahwa hubungan antar variabel dependen dan independen linear.

b. Jika baris deviation from linearity signifikan, ini menunjukkan bahwa sebagian lain variasi hubungan antar variabel ini tidak mengikuti garis linear.

\section{Uji Heterogenitas}

Uji ini digunakan untuk menguji ketidaksamaan varians residual dari satu pengamatan ke pengamatan yang lainnya. Jika varians residual dari satu pengamatan ke pengamatan lainnya tetap maka disebut homokedastisitas, dan jika varians berbeda disebut heteroskedastisitas.

Dasar pengambilan keputusan :

a. Jika ada pola tertentu seperti titik-titik yang membentuk suatu pola tertentu (bergelombang, melebar kemudian menyempit) maka terjadi heteroskedastisitas.

b. Jika ada pola tertentu seperti titik-titik melebar diatas nol dan dibawah angka 0 pada sumbu Y, maka tidak terjadi heteroskedastisitas (Santoso, 2000).

\section{Uji Autokorelasi}

Autokorelasi adalah korelasi antara anggota serangkaian observasi yang diurutkan menurut waktu dan ruang (Gujarati, 1999). Bila dalam suatu model ada korelasi antara kesalahan pengganggu pada periode $\mathrm{t}$ dengan kesalahan pada periode $\mathrm{t}-1$ (sebelumnya). Maka model regresi yang baik adalah regresi yang bebas dari autokorelasi. Secara umum patokannya sebagai berikut :

a. Jika nilai d tepat sama dengan 2, maka tidak terjadi autokorelasi sempurna.

b. Jika nilai $d$ antara 1,5 sampai 2,5 maka data tidak mengalami autokorelasi atau sebagai rule of tumb (aturan ringkas).

c. Jika $d=0$ sampai 1,5 disebut memiliki autokorelasi positif. d. Jika d > 2,5 sampai 4 disebut memiliki autokorelasi negatif.

\section{Uji Multikorelasi}

Uji ini digunakan untuk melakukan pengujin dimana model regresi yang terbentuk memiliki korelasi antara variabel independen dan jika terjadi korelasi maka dinamakan terdapat problem Multikorelasi atau multiko (Santoso, 2000). Uji Multikorelasi adalah VIF (Varians Inflation Factor) dan Tolerance.

Pedomannya suatu regresi yang bebas multikorelasi adalah :

a. Mempunyai nilai VIF disekitar 1 .

b. Mempunyai angka tolerance mendekati 1.

Tabel 1. Tabel multikorelasi

\begin{tabular}{cc}
\hline $\begin{array}{c}\text { Nilai } \\
\text { Koefisien } \\
\text { Beta }\end{array}$ & $\begin{array}{c}\text { Kategori } \\
\text { Pengaruh }\end{array}$ \\
\hline $0,05-0,09$ & Lemah \\
\hline $0,10-0,29$ & Sedang \\
\hline$>0,30$ & Kuat \\
\hline
\end{tabular}

Sumber : Ridwan dan Sunarto, 2007

\section{5) Koefisien Determinan $\left(\mathbf{R}^{2}\right)$}

Koefisien determinan yang biasanya dilambangkan dengan $\mathrm{R}^{2}$ adalah suatu angka yang dapat dijadikan salah satu kriteria untuk nilai kebaikan atau kesesuaian sebuah model regresi. Dalam bahasa sehari koefisien determinan tersebut dapat didefinisikan sebagai bagian atau porsi dari variansi variabel dependen yang dapat diterangkan oleh variabel bebas. Dengan demikian semakin mampu variabel independen menerangkan fluktuasi yang terjadi pada variabel dependent, maka akan semakin besar pula nilai $\mathrm{R}^{2}$ dari model yang dibuat. Dan demikian akan semakin baik atau sesuai pula model regresi tersebut. Sebaliknya jika $\mathrm{R}^{2}$ relatif kecil, maka model yang dibentuk dikategorikan kurang baik atau kurang sesuai.

Secara intuitif model regresi dikatakan baik atau sesuai jika model tersebut memberikan error yang kecil. Dan 
jika kita menguraikan jumlah kuadrat (sum of square) dai data maka akan berlaku JKT $=\mathrm{JKR}+\mathrm{JKE}$ (jumlah kuadrat total $=$ Jumlah kuadra regresi + Jumlah kuadrat error). Dan jika diperhatikan rumus hitung dari $\mathrm{R}^{2}=\mathrm{JKR} / \mathrm{JKT} * 100$, maka makin kecil error, maka makin besar JKR dan main mendekati JKT sehingga $\mathrm{R}^{2}$ akan makin besar. Oleh karena itu jika $\mathrm{R}^{2}$ $=100 \%$ atau $\mathrm{R}=1$, maka itu berarti variable-variabel penjelas yang dimasukkan dalam model tersebut mampu menerangkan semua fluktuasi atau perubahan yang terjadi dalam variable dependent. Kondisi seperti ini hampir mustahil diperoleh, sebaliknya jika $\mathrm{R}^{2}$ $=0 \%$, maka itu berarti variable bebas yang masuk dalam model tersebut sama sekali tidak bisa menjelaskan fluktuasi atau perubahan yang terjadi dalam variable dependent. Jika hal ini terjadi maka model tersebut buruk.

\section{6) $\mathbf{U j i} \mathbf{F}$}

Selain koefisien determinan, untuk menilai kebaikan atau keseuaian sebuah model regresi dapat pula digunakan criteria lain berupa uji F. adapun falsafah yang mendasari criteria ini pada dasarnya hamper sama dengan koefisien determinasi, yaotu jika model yang diperoleh cukup baik atau sesuai, maka semestinya jumlah kuadrat error (JKS=SSE) memiliki nilai yang relative kecil dibandingkan dengan jumlah kuadrat total (JKT-SST) maupun dengan jumlah kuadrat regressi(JKT=SSR). Bertolak belakang dari pemikiran ini apabila model yang dibuat tergolong baik atau sesuai, maka rasio SSR dengan SSE mestinya cukup besar. Untuk menilai apakah rasio antara SSR dengan SSE cukup signifikan atau tidak. Oleh karena itu Fisher membuat patokan dengan table $\mathrm{F}$ yang dapat dijadikan sehingga pengujian ini disebut Uji-F, adapun aturan-aturan sebagai berikut :

$\mathrm{F} \alpha(\mathrm{k}, \mathrm{t}-\mathrm{k}-1)$, maka model dikatakan cukup baik dalam menjelaskan variable dependent
Jika $\mathrm{F}=\mathrm{SSR} / \mathrm{K}$

$\mathrm{SSE} / \mathrm{t}-\mathrm{k}-1$

$\mathrm{K}=$ Banyak Variabel penjelas dalam model

$\mathrm{t}=$ Banyaknya observasi

7) $\mathbf{U j i} \mathbf{t}$

Koefisien regressi yang diperoleh hanyalah suatu dugaan yang sudah barang tentu didalamnya terkandung unsure ketidakpastian. Oleh sebab itum koefisienkoefisien tersebut harus diuji apakah nilainya dapat dianggap sama dengan suatu nilai tertentu, nilai tertentu itu umumnya adalah nol. Karena bila nilai suatu koefisien dapat dianggap sama dengan nol, maka hal itu berate pengaruh variable bebas yang bersangkutan terhadap variable terikat tidaklah signifikan, yang pada gilirannya juga berarti variable tersebut tidak perlu dimasukkan dalam model.

Pada bagian sebelumnya telah pula dibahas prosedur pengujian signifikansi seluruh koefiesien regresi sekaligus dengan mengunakan F-test, pengujian signifikasn masing-masing koefisien yang akan dibahas pada bagian ini hanua perlu dilakukan bila F-Test menunjukan hasil yang signifikan. Sebab bila bila tidak, maka sudah bisa dipastikan bahwa semua koefisien regresi tersebut dapat dianggap sama dengan nol. Dengan demikian pengujian secara sendiri-sendiri ini tidak akan memberikan tambahan informasi apa-apa, bila pengujian dengan F-Test tidak menunjukan hasil yang signifikan.

Adapun falsafah yang mendasari pengujian individual koefisien regresi ini adalah sebagai berikut. Jika bk adalah nilai dengan dugaan koefisien regressi untuk variable bebas $\mathrm{Xk}$, maka agar bk tersebut dapat dikatakan mempunyai pengaruh uang cukup berarti atau signifikan terhadap variable terikat, haruslah rasio antaraa bk dengan standard error-nya relative besar. Artinya nilai dugaan haruslah memiliki tingkat kesalahan yang relative kecil. Jika rasio antar bk dengan standard error-nya dilambangkan dengan $t$, 
maka formula untuk $\mathrm{t}$ dapat dituliskan sebagai berikut :

$$
\mathrm{t}=\mathrm{b}_{\mathrm{k}} / \mathrm{S}_{\mathrm{bk}}
$$

Untuk mendapatkan gambaran tentang relative besar kecilnya nilai $\mathrm{t}$ dalam formula tersebut diatas, diperlukan suatu nilai pembanding yang dapat dijadikan sebagai patokan. Nilai pembanding tersebut didalam ekonometri dikenal sebagai nilai table distribusi tstudent dengan level of significance $\alpha$ dan dengan degree of freedom t-k-1. Adapun aturan penarikan kesimpulannya adalah sebagai berikut :

a. Jika $t>t_{\alpha(T-k-1)}$, maka koefisien regressi bk dikatakan signifikan, artinya variable bebas $X_{k}$ mempunyai pengaruh yang cukup berarti terhadap variable terikat $\mathrm{Y}_{\mathrm{t}}$.

b. Jika $t<t_{\alpha(T-k-1)}$, maka koefisien regressi bk dikatakan tidak signifikan.

c. Jika $\mathrm{t}=\mathrm{t}_{\alpha(\mathrm{T}-\mathrm{k}-1)}$, maka tidak dapat ditarik kesimpulan apa-apa, namun sama halnya dengan F-test, kemungkinan terjadi seperti hal ini sangat kecil sekali.

\section{8) Hipotesis Statistik}

Hipotesis persamaan regresi 1 :

1. Ho : $\beta_{1}=\beta_{2}=0$, Tidak ada pengaruh antara mutasi kerja dan pelatihan terhadap semangat kerja.

Ha : paling sedikit $\beta_{\mathrm{i}} \neq 0, \quad$ Ada pengaruh antara mutasi kerja dan pelatihan kerja terhadap semangat kerja.

2. Ho : $\beta_{1}=0$, Tidak ada pengaruh antara mutasi kerja terhadap semangat kerja Ha : $\beta_{1} \neq 0$, Ada pengaruh antara mutasi kerja terhadap semangat kerja.

3. Ho : $\beta_{2}=0$, Tidak ada pengaruh antara pelatihan kerja terhadap semangat kerja.

Ha : $\beta_{2} \neq 0$, Ada pengaruh antara pelatihan kerja terhadap semangat kerja.

Hipotesis persamaan regresi 2 :

4. Ho : $\beta_{3}=\beta_{4}=\beta_{5}=0$, Tidak ada pengaruh antara mutasi kerja, pelatihan kerja dan semangat kerja terhadap terhadap prestasi kerja.
Ha : paling sedikit $\beta_{i} \neq 0$, Ada pengaruh antara mutasi kerja, pelatihan kerja dan semangat kerja terhadap terhadap prestasi kerja.

5. Ho : $\beta_{3}=0$, Tidak ada pengaruh antara mutasi kerja terhadap prestasi kerja.

$\mathrm{Ha}: \beta_{3} \neq 0$, Ada pengaruh antara mutasi kerja terhadap prestasi kerja.

6. Ho : $\beta_{4}=0$, Tidak ada pengaruh antara prestasi kerja terhadap prestasi kerja.

Ha : $\beta_{4} \neq 0$, Ada pengaruh antara prestasi kerja terhadap prestasi kerja.

7. Ho : $\beta_{3}=\beta_{4}=0$, Tidak ada pengaruh antara mutasi kerja dan pelatihan kerja terhadap prestasi kerja.

Ha : paling sedikit $\beta_{i} \neq 0$, Ada pengaruh antara mutasi kerja dan pelatihan

kerja terhadap prestasi kerja.

\section{HASIL DAN PEMBAHASAN}

1. Uji Coba Instrumen.

Uji validitas yang dibuat oleh peneliti menggunakan tingkat kepercayaan $95 \%$, dimana $\mathrm{df}=\mathrm{n}-2$, nilai $\mathrm{n}$ dalam hal ini yaitu 100 sehingga $\mathrm{df}=100-2=98$, dengan begitu diperoleh nilai $\mathrm{t}$ tabel $=$ 1,681 . Selanjutnya dengan menggunakan rumus $r$ tabel, maka diperoleh nilai $r$ tabel $=0,195$.

Dasar pengambilan keputusan pada uji validitas adalah sebagai berikut :

- Jika $r$ hitung > 0,195, maka data valid

- Jika $r$ hitung < 0,195, maka data tidak valid

Sedangkan, dasar pengambilan keputusan pada uji relaibilitas adalah sebagai berikut :

- Jika Cronbach Alpha > 0,60 maka data reliabel

- Jika Cronbach Alpha < 0,60 maka data tidak reliable

\section{Uji Validitas dan Reliabilitas Variabel Prestasi Kerja (Y)}

Variabel X1 diukur melalui butir pertanyaan $1,2,3,4,5,6,7,8,9,10,11$, $12,13,14,15,16,17,18,19,20$ dengan menggunakan bantuan program SPSS 
diperoleh hasil sebagai berikut dalam tabel 2:

\section{Tabel 2 Uji Validitas dan Reliabilitas} Variabel Prestasi Kerja (Y)

\begin{tabular}{ccc}
\hline Pertanyaan & r hitung & Keterangan \\
\hline 1 & 0,357 & Valid \\
\hline 2 & 0,552 & Valid \\
\hline 3 & 0,328 & Valid \\
\hline 4 & 0,380 & Valid \\
\hline 5 & 0,198 & Valid \\
\hline 6 & 0,164 & Tidak Valid \\
\hline 7 & 0,355 & Valid \\
\hline 8 & 0,253 & Valid \\
\hline 9 & 0,193 & Tidak Valid \\
\hline 10 & 0,306 & Valid \\
\hline 11 & 0,285 & Valid \\
\hline 12 & 0,661 & Valid \\
\hline 13 & 0,244 & Valid \\
\hline 14 & 0,208 & Valid \\
\hline 15 & 0,193 & Tidak Valid \\
\hline 16 & 0,144 & Tidak Valid \\
\hline 17 & 0,164 & Tidak Valid \\
\hline 18 & 0,294 & Valid \\
\hline 19 & 0,388 & Valid \\
\hline 20 & 1,000 & Valid \\
\hline
\end{tabular}

$\mathrm{r}$ tabel $=0,195$

$\mathbf{T}$

\begin{tabular}{ccr}
\hline \multicolumn{3}{c}{ Reliability Statistics } \\
\hline \multicolumn{3}{c}{ Cronbach's } \\
Alpha Based \\
on \\
Cronbach's & Standardized \\
Alpha & Items & N of Items \\
\hline .938 & .940 & 15 \\
\hline
\end{tabular}

Untuk menguji realibilitas data, maka dari hasil perhitungan SPSS, diperoleh nilai Cronbach Alpha $=0,938(\mathrm{r}$ tabel $=0,195)$ maka data reliabel. Jadi untuk variabel Y yaitu Prestasi Kerja yang dapat dipergunakan untuk proses analisa selanjutnya adalah data jawaban atas butir pertanyaan $1,2,3,4,5,7,8,10,11,12$, 13, 14,18, 19 dan 20.

\section{Uji Validitas dan Reliabilitas Variabel Semangat Kerja (Z)}

Variabel X1 diukur melalui butir pertanyaan $1,2,3,4,5,6,7,8,9,10,11$, $12,13,14,15,16,17,18,19,20$ dengan menggunakan bantuan program SPSS diperoleh hasil sebagai berikut dalam table 3:

\section{Tabel 3 Uji Validitas dan Reliabilitas} Variabel Semangat Kerja (Z)

\begin{tabular}{ccc}
\hline Pertanyaan & r hitung & Keterangan \\
\hline 1 & 0,371 & Valid \\
\hline 2 & 0,552 & Valid \\
\hline 3 & 0,361 & Valid \\
\hline 4 & 0,380 & Valid \\
\hline 5 & 0,345 & Valid \\
\hline 6 & 0,497 & Valid \\
\hline 7 & 0,497 & Valid \\
\hline 8 & 0,036 & Tidak Valid \\
\hline 9 & 1,000 & Valid \\
\hline 10 & 0,264 & Valid \\
\hline 11 & 0,475 & Valid \\
\hline 12 & 0,280 & Valid \\
\hline 13 & 0,363 & Valid \\
\hline 14 & 0,289 & Valid \\
\hline 15 & 0,418 & Valid \\
\hline 16 & 0,354 & Valid \\
\hline 17 & 0,108 & Tidak Valid \\
\hline 18 & 0,406 & Valid \\
\hline 19 & 0,369 & Valid \\
\hline 20 & 1,000 & Valid \\
\hline
\end{tabular}

$\mathrm{r}$ tabel $=0,195$

Tabel 4. Hasil Uji Reliabilitas Reliability Statistics

Cronbach's

Alpha Based

on

Cronbach's Standardized

\begin{tabular}{|c|c|c|}
\hline Alpha & Items & $\mathrm{N}$ of Items \\
\hline .956 & .960 & 18 \\
\hline
\end{tabular}

maka dari hasil perhitungan SPSS, diperoleh nilai Cronbach Alpha $=0,956(\mathrm{r}$ tabel $=0,195)$ maka data reliabel. Jadi untuk variabel $\mathrm{Z}$ yaitu Semangat Kerja yang dapat dipergunakan untuk proses analisa selanjutnya adalah data jawaban atas butir pertanyaan $1,2,3,4,5,6,7$, $9,10,11,12,13,14,15,16,18,19,20$.

\section{Uji Validitas dan Reliabilitas} Variabel Mutasi (X1)

Variabel X1 diukur melalui butir pertanyaan $1,2,3,4,5,6,7,8,9,10$, $11,12,13,14,15,16,17,18,19,20$ 
dengan menggunakan bantuan program SPSS diperoleh hasil sebagai berikut dalam tabel 5 :

Tabel 6 Uji Validitas dan Reliabilitas Variabel Mutasi (X1)

\begin{tabular}{|c|c|c|}
\hline Pertanyaan & r hitung & Keterangan \\
\hline 1 & 0,480 & Valid \\
\hline 2 & 0,719 & Valid \\
\hline 3 & 0,498 & Valid \\
\hline 4 & 0,294 & Valid \\
\hline 5 & 0,470 & Valid \\
\hline 6 & 0,522 & Valid \\
\hline 7 & 0,430 & Valid \\
\hline 8 & 0,507 & Valid \\
\hline 9 & 0,373 & Valid \\
\hline 10 & 0,350 & Valid \\
\hline 11 & 0,286 & Valid \\
\hline 12 & 0,512 & Valid \\
\hline 13 & 0,750 & Valid \\
\hline 14 & 0,305 & Valid \\
\hline 15 & 0,279 & Valid \\
\hline 16 & 0,508 & Valid \\
\hline 17 & 0,541 & Valid \\
\hline 18 & 0,268 & Valid \\
\hline 19 & 0,588 & Valid \\
\hline 20 & 1,000 & Valid \\
\hline
\end{tabular}

$\mathrm{r}$ tabel $=0,195$

Tabel 5. Hasil Uji Reliabilitas Reliability Statistics

\begin{tabular}{ccr}
\hline & \multicolumn{2}{c}{ Cronbach's } \\
& Alpha Based & \\
on & \\
Cronbach's & Standardized \\
Alpha & Items & N of Items \\
\hline .940 & .942 & 20
\end{tabular}

Untuk menguji realibilitas data, maka dari hasil perhitungan SPSS, diperoleh nilai Cronbach Alpha $=0,940$ ( $\mathrm{r}$ tabel $=0,195)$ maka data reliabel. Jadi untuk variabel X1 yaitu Mutasi Kerja yang dapat dipergunakan untuk pross analisa selanjutnya adalah data jawaban atas butir pertanyaan $1,2,3,4,5,6,7,8,9,10,11$, $12,13,14,15,16,17,18,19$ dan 20.

\section{Uji Validitas dan Reliabilitas Variabel Pelatihan Kerja (X2) \\ Variabel X2 diukur melalui butir} pertanyaan $1,2,3,4,5,6,7,8,9,10,11$, $12,13,14,15,16,17,18,19,20$ dengan menggunakan bantuan program SPSS diperoleh hasil sebagai berikut dalam table 6 :

Tabel. 6

Uji Validitas dan Reliabilitas Variabel Pelatihan Kerja (X2)

\begin{tabular}{|c|c|c|}
\hline Pertanyaan & r hitung & Keterangan \\
\hline 1 & 0,357 & Valid \\
\hline 2 & 0,552 & Valid \\
\hline 3 & 0,461 & Valid \\
\hline 4 & 0,108 & Tidak Valid \\
\hline 5 & 0,408 & Valid \\
\hline 6 & 0,140 & Tidak Valid \\
\hline 7 & 0,220 & Valid \\
\hline 8 & 0,086 & Tidak Valid \\
\hline 9 & 0,328 & Valid \\
\hline 10 & 0,144 & Tidak Valid \\
\hline 11 & 0,183 & Tidak Valid \\
\hline 12 & 0,002 & Tidak Valid \\
\hline 13 & 0,230 & Valid \\
\hline 14 & 0,102 & Tidak Valid \\
\hline 15 & $-0,079$ & Tidak Valid \\
\hline 16 & 0,083 & Tidak Valid \\
\hline 17 & 0,258 & Valid \\
\hline 18 & 0,406 & Valid \\
\hline 19 & 0,369 & Valid \\
\hline 20 & 1,000 & Valid \\
\hline r table $=0,195$ & & \\
\hline & & \\
\hline & &
\end{tabular}

\section{Tabel 7. Hasil Uji Reliabilitas Reliability Statistics}

Cronbach's Alpha

Based on

Cronbach's Standardized

\begin{tabular}{crr} 
Alpha & Items & N of Items \\
\hline .865 & .869 & 11
\end{tabular}
maka dari hasil perhitungan SPSS, diperoleh nilai Cronbach Alpha $=0,865$ (r tabel $=0,195)$ maka data reliabel.Jadi untuk variabel X2 yaitu Pelatihan yang dapat dipergunakan untuk pross analisa selanjutnya adalah data jawaban atas butir 
pertanyaan $1,2,3,5,7,9,13,17,18,19$ dan 20.

\section{Pengujian Asumsi Analisis Regresi}

\section{a. Uji persamaan 1}

Uji berikutnya adalah Analisa persamaan 1 dimana analisa pengaruh variabel mutasi dan pelatihan terhadap semangat kerja dapat di gambarkan sebagai berikut :

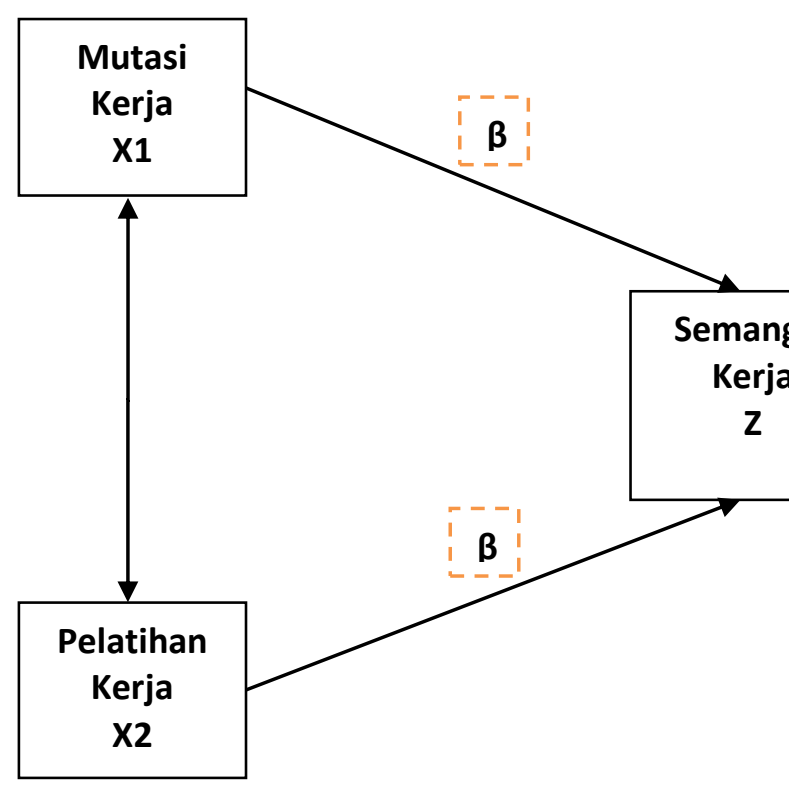

Gambar 1. Persamaan 1

Persamaaan 1

$$
Z=\beta o+\beta_{1} x_{1}+\beta_{2 \times 2}
$$

b. Uji Normalitas Variabel Mutasi (X1)

dan Pelatihan Kerja (X2) terhadap Variabel Semangat Kerja (Z)

Dan data tersebut diolahdengan mempergunakan SPSS versi 19 diperoleh hasil sebagai berikut :

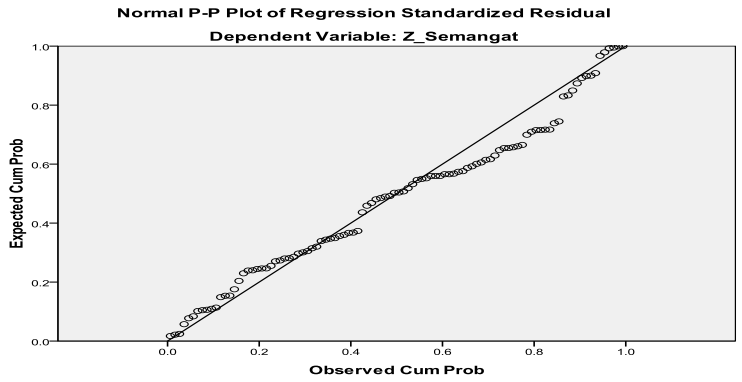

Gambar 2. Hasil Uji Normalitas:

Pengujian Normalitas dilakukan untuk melihat apakah dalam model regresi, variabel dependen dan independennya memiliki distribusi normal atau tidak. Jika data menyebar di sekitar garis dan mengikuti arah aris diagonal maka model regresinya memenuhi asumsi normalitas (Gujarati,2003).

Dari gambar diatas mengindikasikan bahwa model regresi telah memenuhi asumsi normalitas sesuai yang telah dikemukakan diatas, karena terlihat data menyebar disekitar garis diagonal dan mengikti garis diagonal, sehingga data dalam model regresi penelitian ini cenderung Normal.

c. Uji MultikolinieritasVariabel Mutasi Kerja (X1) dan Pelatihan Kerja (X2)terhadap Variabel Semangat Kerja (Z)

Uji multikolinieritas bertujuan ik menguji apakah variabel dalam lel regresi ditemukan adanya korelasi ra variable bebas (independen).Model esi yang baik seharusnya tidak terjadi lasi diantara variable bebas. Uji Multikolinieritas dapat dilakukan dengan melihat VIF (Variance Inflation Factors) dan nilai tolerance. Jika VIF < 10 dan nilai tolerance $>0,10$ maka tidak terjadi gejala Multikolinieritas (Ghozali, 2006). Berdasarkan hasil perhitungan Analisa Regresi dengan menggunakan SPSS 19 didapatkan hasil Uji Multikolinearitas sebagai berikut :

Tabel 8. Uji Multikolinieritas

Collinearity Statistics

\begin{tabular}{|c|c|c|c|c|}
\hline Model & Partial & Part & Tolerance & VIF \\
\hline \multicolumn{5}{|l|}{ (Constant) } \\
\hline $\begin{array}{l}\text { X1_Mutasi } \\
\text { kerja }\end{array}$ & .871 & .686 & .666 & 1.503 \\
\hline $\begin{array}{l}\text { X2_Pelatihan } \\
\text { Kerja }\end{array}$ & .264 & .106 & .666 & 1.503 \\
\hline
\end{tabular}

a. Dependent Variable: Z_Semangat

Berdasarkan nilai Variance Inflasi Factor (VIF) yang tertera pada tabel 8, tidak terjadi multikolinearitas pada variabel mutasi kerja (X1) dan pelatihan kerja $(\mathrm{X} 2)$ dengan nilai $\mathrm{VIF}<10$. 


\section{d. Uji Heterokedastisitas Variabel Mutasi Kerja (X1) dan Pelatihan Kerja (X2)terhadap Variabel Semangat Kerja $(Z)$}

Heterokedastisitas digunakan untuk menguji apakah dalam model regresi terjadi ketidaksamaan variasi residual dari suatu pengamatan yang lain, dasar pengambilan keputusannya adalah jika pola tertentu, seperti titik poin yang ada membentuk suatu pola yang teratur maka dinyatakan terjadi heterokedastisitas, namun apabila menyebar di bawah dan di atas angka 0 pada sumbu $\mathrm{Y}$, maka tidak terjadi heterokedastisitas seperti tertulis dalam penjelasan buku (Santoso:2000). Jika pada variasi residual dari satu pengamatan ke pengamatan yang lain tetap, maka disebut homokedastisitas, dalam hal ini model yang baik adalah tidak terjadi heterokedastisitas seperti tertulis dalam penjelasan buku (Arief, 1993:

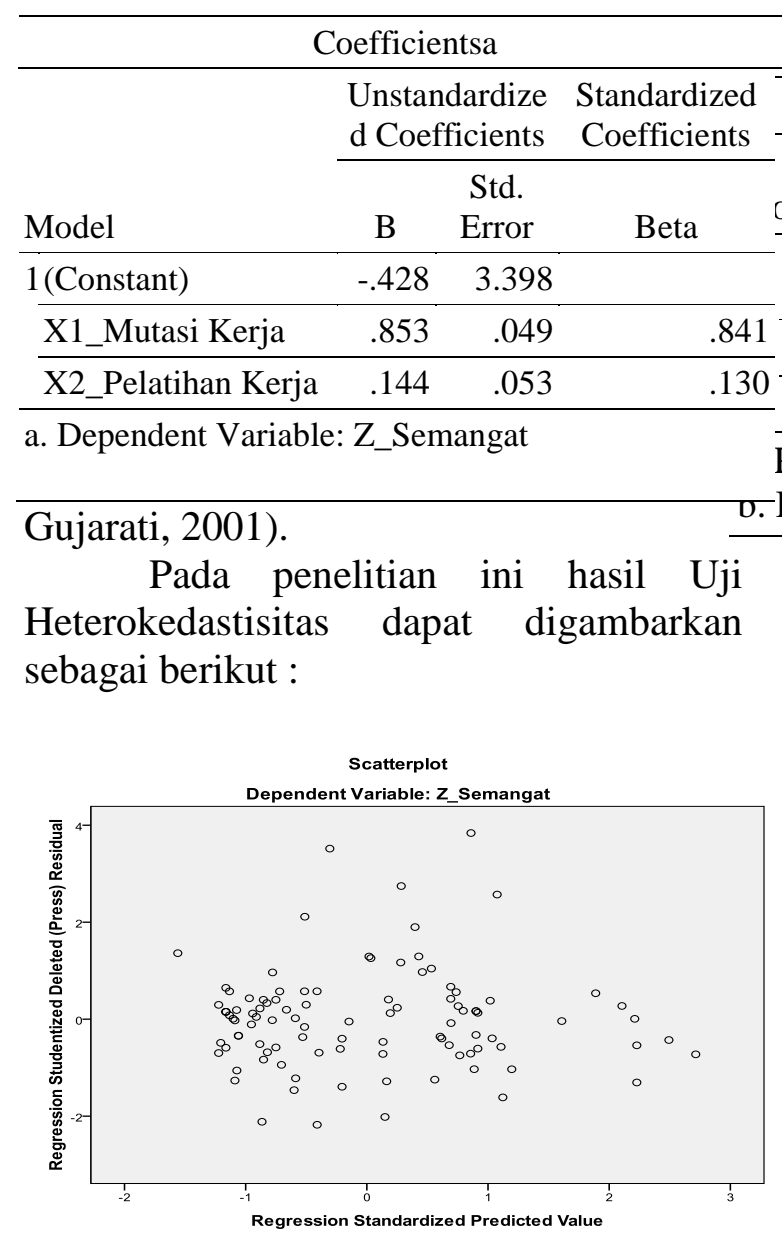

Gambar 3. Hasil Uji Heteroskedastisitas

Pada penelitian ini hasil Uji Heterokedastisitas dapat digambarkan sebagai berikut :

Gambar diatas memperlihatkan titik - titik menyebar secara acak, tidak membentuk pola yang jelas/teratur, serta tersebar baik di bawah angka 0 pada sumbu $Y$ dengan demikian dapat disimpulkan tidak terjadi Heterokedastisitas.

e. Pengujian Secara Gabungan Variabel Mutasi Kerja (X1) dan Pelatihan Kerja (X2) terhadap Variabel Semangat Kerja (Z)

Guna mengetahui model regresi (apakah model regresi sudah benar atausalah), maka diperlukan uji hipotesis yaitudengan membandingkan angka taraf signifansi (sig) hasil penghitungan dengan taraf signifikansi 0,05 (5\%). kriterianya sebagai berikut:

- Jika sig penelitian < 0,05 maka Hoditolak dan Ha diterima.

- Jika sig penelitian > 0,05 maka Hoditerima dan Ha ditolak

Tabel 9. Hasil Pengujian Secara Gabungan

\begin{tabular}{|c|c|c|c|c|c|}
\hline \multicolumn{6}{|c|}{ ANOVA $^{b}$} \\
\hline odel & $\begin{array}{l}\text { Sum of } \\
\text { Squares }\end{array}$ & $\mathrm{df}$ & $\begin{array}{l}\text { Mean } \\
\text { Square }\end{array}$ & $\mathrm{F}$ & Sig. \\
\hline Regression & 9233.692 & 2 & 4616.846 & 275.782 & $.000^{\mathrm{a}}$ \\
\hline Residual & 1623.868 & 97 & 16.741 & & \\
\hline Total & 10857.56 & 99 & & & \\
\hline
\end{tabular}

Predictors: (Constant), X2_Pelatihan, X1_Mutasi .Dependent Variable: Z_Semangat

Berdasarkan tabel diatas, maka Perhitungan angka signifikansi sebesar 0,000< 0,05 maka Ho ditolak dan $\mathrm{Ha}$ diterima. Artinya, ada hubungan signifikan antara mutasi kerja,sistem pelatihan kerja dan semangat kerja.

Persamaan 1 sebagai berikut :

$$
\begin{aligned}
& Z=\beta o+\beta_{1} x_{1}+\beta_{2 \times 2} \\
& Z=-0,428+0,853 X 1+0,144 X 2
\end{aligned}
$$

Penjelasannya sebagai berikut :

1. Nilai konstanta adalah sebesar $-0,428$ yang berarti bahwa jika tidak ada variabel independen yang terdiri dari mutasi kerja dan pelatihan kerjamaka semangat kerja sendiri akan bernilai 0,428. Hasil ini dapat dimaknakan 
bahwa semangat kerjaakanturun sebesar $-0,428$ dari periode sebelumnya jika organisasi atau instansi tidak memiliki sistem mutasi kerja dan pelatihan kerja.

2. Mutasi kerja (X1) mempunyai pengaruh positif terhadap semangat kerja, dengan koefisien regresi sebesar 0,853 yang berarti bahwa mutasi kerjaakan meningkat 1(satu) kali, maka semangat kerja akan meningkat sebesar 0,853 .

3. Pelatihan kerja (X2) mempunyai pengaruh positif terhadap semangat kerja, dengan koefisien regresi sebesar 0,144 yang berarti bahwa pelatihan kerja akan meningkat 1 kali yang berdampak pada peningkatan semangat kerjasebesar 0,144.

Tabel 10. Hasil Uji Koefisien Determinasi

$$
\text { Model Summary }{ }^{\mathrm{b}}
$$

\begin{tabular}{lcrrr} 
Model & R & $\begin{array}{c}\text { R } \\
\text { Square }\end{array}$ & $\begin{array}{c}\text { Adjusted R } \\
\text { Square }\end{array}$ & $\begin{array}{l}\text { Std. Error of } \\
\text { the Estimate }\end{array}$ \\
\hline 1 & $.922^{\mathrm{a}}$ & .850 & .847 & 4.092
\end{tabular}

a. Predictors: (Constant), X2_Pelatihan Kerja, X1_Mutasi Kerja

b. Dependent Variable: Z_Semangat Kerja

Tabel di atas Menunjukan nilai $\mathrm{R}$ Square sebesar 0,850hal ini berarti bahwa variabel mutasikerja (X1) dan pelatihan kerja (X2) mempengaruhi variabel semangat kerja (Z) sebesar $85 \%$, dan sisanya dipengaruhi oleh variabel-variabel lain.

\section{f. Pengujian secara Parsial}

Dalam pengujian secara parsial ini, untuk melihat besarnya pengaruh variabel mutasi kerja, pelatihan kerjadan semangat kerja secara sendiri-sendiri atau parsial, digunakan Uji t, sedangkan untuk melihat besarmya pengaruh, digunakan angka Beta atau Standardized Coeffecient di bawah ini.
Tabel 11. Pengujian secara Parsial

\begin{tabular}{lrr}
\hline & \multicolumn{1}{c}{$\mathrm{T}$} & \multicolumn{1}{c}{ Sig. } \\
\cline { 2 - 3 } Model & & \\
\hline 1 (Constant) & -.126 & .900 \\
\hline X1_Mutasi Kerja & 17.477 & .000 \\
\hline X2_Pelatihan Kerja & 2.691 & .008 \\
\hline
\end{tabular}

a. Dependent Variable: Z_Semangat

1. Pengaruh Variabel Mutasi kerja (X1) terhadap Variabel Semangat kerja (Z).

Hasil penghitungan SPSS maka diperoleh sig $\rho$ _value adalah 0.000 .Nilai signifikansi dari mutasi kerja terhadap semangat kerja yaitu $0.000<0.05$, sehingga Ho ditolak dan $\mathrm{Ha}$ diterima. Artinya ada pengaruh signifikan dari mutasi kerja terhadap semangat kerja. Adapun besar pengaruhnya yaitu 0,841 yang berarti mutasi kerja memberikan pengaruh sebesar $84,1 \%$ terhadap semangat kerja.

2. Pengaruh Variabel Pelatihan Kerja (X2) terhadap Semangat Kerja (Z).

Hasil penghitungan SPSS maka diperoleh sig $\rho$ _value adalah 0.008.Nilai signifikansi dari pelatihan kerja terhadap semangat kerja yaitu $0.008<0.05$, sehingga Ho ditolak dan $\mathrm{Ha}$ diterima. Artinya ada pengaruh signifikan dari pelatihan kerja terhadap semangat kerja. Adapun besar pengaruhnya yaitu 0,130 yang berarti pelatihan kerja memberikan pengaruh sebesar $13,0 \%$ terhadap semangat kerja.

\section{g. Uji Persamaan 2}

Uji berikutnya adalah analisa persamaan 2 dimana analisa Pengaruh variabel mutasi, pelatihan dan semangat kerja terhadap Prestasi Kerja dapat digambarkan sebagai berikut :

\begin{tabular}{lllll}
\hline \multicolumn{5}{c}{ Coefficients $^{\mathrm{a}}$} \\
\hline & \multicolumn{4}{c}{ Collinearity Statistics } \\
\cline { 2 - 5 } Model & Partial & Part & Tolerance & VIF \\
\hline 1 (Constant) & & & & \\
\hline X1_Mutasi & .871 & .686 & .666 & 1.503 \\
$\begin{array}{l}\text { Kerja } \\
\text { X2_Pelatihan } \\
\text { Kerja }\end{array}$ & .264 & .106 & .666 & 1.503 \\
\hline \begin{tabular}{l} 
a. Dependent Variable: Z_Semangat \\
\hline
\end{tabular} & & & \\
\hline
\end{tabular}




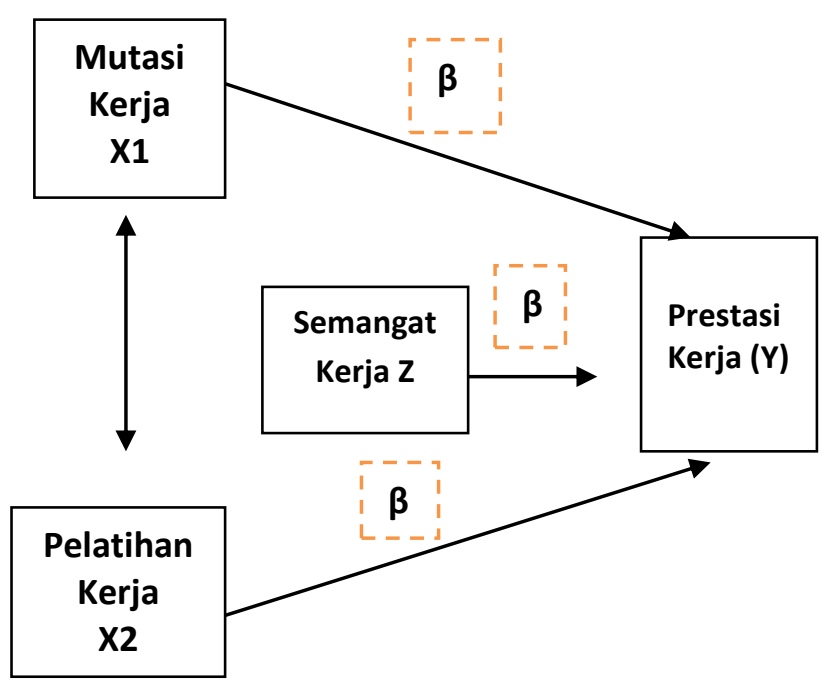

Persamaan 2.

$\bar{Y}=\alpha_{0}+\alpha_{1} X_{1}+\alpha_{2} X_{2}+\alpha_{3} Z$

h. Uji Normalitas Variabel Mutasi

Kerja (X1) danPelatihan Kerja (X2) terhadap Variabel Semangat Kerja (Z) serta dampaknya terhadap Variabel Prestasi Kerja (Y)

Berdasarkan hasil perhitungan data dari SPSS versi 19 didapat gambar Normalitas sebagai berikut :

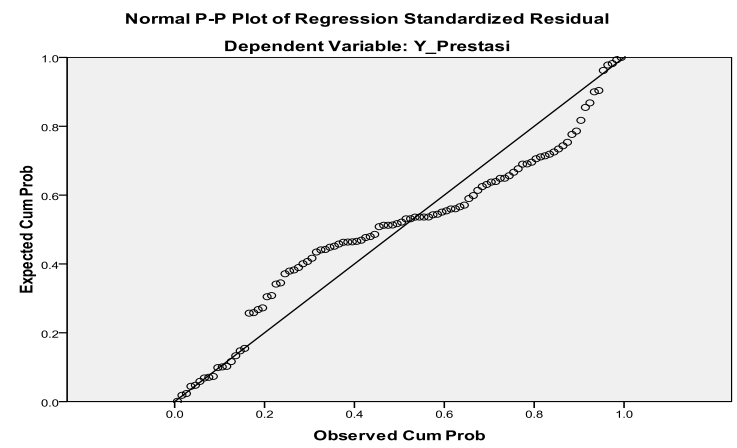

Dari gambar diatas mengindikasikan bahwa model regresi telah memenuhi asumsi normalitas sesuai yang telah dikemukakan diatas, karena terlihat data menyebar disekitar garis diagonal dan mengikti garis diagonal, sehingga data dalam model regresi penelitian ini cenderung normal.
i. Uji Multikolinearitas Variabel Mutasi Kerja (X1) dan Pelatihan Kerja (X2)terhadap Variabel Semangat Kerja (Z) serta dampaknya terhadap variabel Prestasi Kerja (Y)

Berdasarkan hasil perhitungan data dari SPSS versi 19 didapat data koefisien sebagai berikut :

Tabel 12. Hasil Uji Multikolinearitas

Berdasarkan nilai Variance Inflasi Factor yang tertera pada gambar, tidak terjadi multikolinearitas pada variabel Mutasi (X1), Pelatihan (X2) dan Semangat Kerja (Y) dengan nilai VIF $<10$.

j. Uji Heterokedastisitas Variabel

Mutasi Kerja (X1) dan Pelatihan

Kerja (X2) terhadap Variabel

Semangat Kerja (Z) serta dampaknya terhadap Variabel Prestasi Kerja (Y)

Berdasarkan hasil perhitungan data dari SPSS versi 19 didapat gambar Heterokedastisitas seagai berikut :

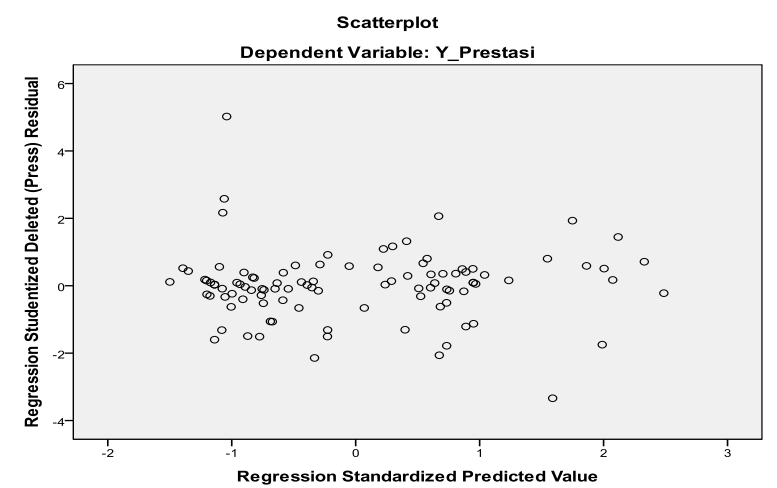

Gambar diatas memperlihatkan titik - titik menyebar secara acak, tidak membentuk pola yang jelas/teratur, serta tersebar baik di bawah angka 0 pada sumbu $Y$ dengan demikian dapat disimpulkan tidak terjadi Heterokedastisitas.

k. Uji Secara Gabungan Variabel Mutasi Kerja (X1) dan Pelatihan Kerja (X2) terhadap Variabel Semangat $\operatorname{Kerja}(Z) \quad$ serta dampaknya terhadap Variabel Prestasi Kerja (Y)

Guna mengetahui model regresi (apakah model regresi sudah benar atausalah),maka diperlukan uji hipotesis yaitudengan membandingkan angka taraf signifansi (sig) hasil penghitungan dengan taraf signifikansi 0,05 (5\%). kriterianya sebagai berikut: 
- Jika sig penelitian < 0,05 maka Hoditolak dan Haditerima.

- Jika sig penelitian > 0,05 maka Hoditerima dan Haditolak

Tabel 13. Hasil Hasil Pengujian Secara Gabungan

\begin{tabular}{|c|c|c|c|c|c|c|}
\hline \multicolumn{7}{|c|}{ ANOVA $^{b}$} \\
\hline \multicolumn{2}{|c|}{ Model } & $\begin{array}{l}\text { Sum of } \\
\text { Squares }\end{array}$ & Df & $\begin{array}{l}\text { Mean } \\
\text { Square }\end{array}$ & $\mathrm{F}$ & Sig. \\
\hline \multirow[t]{3}{*}{1} & Regression & 8818.587 & & 2939.529 & 117.113 & $.000^{\mathrm{a}}$ \\
\hline & Residual & 2409.603 & 96 & 25.100 & & \\
\hline & Total & 11228.190 & 99 & & & \\
\hline
\end{tabular}

a. Predictors: (Constant), Z_Semangat Kerja, X2_Pelatihan Kerja, X1_Mutasi Kerja

b. Dependent Variable: Y_Prestasi Kerja kerja, pelatihan kerja dan semangat kerja.

2. Mutasi kerja (X1) mempunyai pengaruh positif terhadap prestasi kerja, dengan koefisien regresi sebesar 0,134 yang berarti bahwa mutasi kerja akan meningkat 1 kali, maka prestasi kerja akan meningkat sebesar 0,134.

3. Pelatihan kerja (X2) mempunyai pengaruh positif terhadap prestasi kerja, dengan koefisien regresi sebesar 0,185 yang berarti bahwa pelatihan kerja akan meningkat 1 kali yang berdampak pada peningkatan prestasi kerja sebesar 0,185.

4. Semangat kerja (Y) mempunyai pengaruh positif terhadap prestasi kerja, dengan koefisien regresi sebesar 0,666 yang berarti bahwa semangat kerja akan meningkat 1 kali yang berdampak pada peningkatan prestasi kerka sebesar 0,666 .

Tabel 14. Hasil Uji Koefisien

Determinasi

\begin{tabular}{|c|c|c|c|c|}
\hline \multicolumn{5}{|c|}{ Model Summary $^{b}$} \\
\hline Model & $\mathrm{R}$ & $\begin{array}{c}\mathrm{R} \\
\text { Square }\end{array}$ & $\begin{array}{l}\text { Adjusted R } \\
\text { Square }\end{array}$ & $\begin{array}{l}\text { Std. Error of the } \\
\text { Estimate }\end{array}$ \\
\hline 1 & $.886^{\mathrm{a}}$ & .785 & .779 & 5.010 \\
\hline
\end{tabular}

Tabel di atas menunjukan nilai $\mathrm{R}$ Square sebesar 0,785hal ini berarti bahwa variabel mutasikerja (X1), pelatihan kerja (X2) dan semangat kerja mempengaruhi variabel prestasi kerja (Z) sebesar 78,5\%, dan sisanya dipengaruhi oleh variabel lainlain.

\section{Pengujian secara Parsial}

Untuk melihat besarnya pengaruh variabel mutasi, pelatihan kerja,semangat kerjaterhadap prestasi kerja secara sendirisendiri/parsial, sedangkanuntuk melihat besamya pengaruh, digunakan angka Beta atau Standardized Coeffecientdi bawah ini.

Tabel 15 Pengujian secara Parsial 


\begin{tabular}{lcr}
\hline \multicolumn{3}{c}{ Coefficients $^{\mathrm{a}}$} \\
\hline Model & $\mathrm{t}$ & \multicolumn{1}{c}{ Sig. } \\
\hline 1 (Constant) & .179 & .858 \\
\cline { 2 - 2 } X1_Mutasi Kerja & 1.100 & .274 \\
\cline { 2 - 2 } X2_Pelatihan Kerja & 2.721 & .008 \\
\cline { 2 - 2 } Z_Semangat Kerja & 5.360 & .000 \\
\hline
\end{tabular}

a. Dependent Variable: Y_Prestasi Hasil penghitungan SPSS maka diperoleh sig $\rho \_$value adalah 0,274 . Nilai signifikansi dari mutasi kerja terhadap prestasi kerja yaitu $0,274>0.05$, sehingga Ho diterima dan Ha ditolak. Artinya tidak ada pengaruh signifikan dari mutasi kerja terhadap prestasi kerja. Adapun besar pengaruhnya yaitu 0,130 , yang berarti mutasi kerja memberikan pengaruh sebesar 13,0\% terhadap prestasi kerja.

1. Pengaruh Variabel Pelatihan Kerja (X2)terhadap Prestasi Kerja (Y)

Hasil penghitungan SPSS maka diperoleh sig $\rho \_v a l u e$ adalah 0,008 . Nilai signifikansi dari pelatihan kerja terhadap prestasi kerja yaitu $0,008<0.05$, sehingga Ho ditolak dan Ha diterima. Artinya ada pengaruh signifikan dari pelatihan kerja terhadap prestasi kerja. Adapun besar pengaruhnya yaitu 0,163 , yang berarti mutasi kerja memberikan pengaruh sebesar $16,3 \%$ terhadap prestasi kerja.

2. Pengaruh Semangat Kerja terhadap Prestasi Kerja

Hasil penghitungan SPSS maka diperoleh sig $\rho$ _value adalah 0,000 . Nilai signifikansi dari semangat kerja terhadap prestasi kerja yaitu $0,000<0.05$, sehingga Ho ditolak dan Ha diterima. Artinya ada pengaruh signifikan dari semangat kerja terhadap prestasi kerja. Adapun besar pengaruhnya yaitu 0,665 yang berarti mutasi kerja memberikan pengaruh sebesar 66,5\% terhadap prestasi kerja.

\section{PENUTUP}

\section{Kesimpulan}

Berdasarkan hasil analisis data yang telah dilakukan terhadap seluruh data yang diperoleh, maka dapat diambil kesimpulan sebagai berikut:

1. Dalam analisa hipotesis pengaruh penerapan mutasi kerja, pelatihan kerja terhadap semangat kerja didapatkan suatu hubungan kausal secara langsung dan persamaan regresi $\mathrm{Z}=-0,428+$ $0,853 \mathrm{X} 1+0,144 \mathrm{X} 2$, artinya setiap satu pengaruh penerapan mutasi kerja dan pelatihan kerja akan berdampak sebesar nilai $\mathrm{b}$ diatas baik untuk X1 maupun $\mathrm{X} 2$ terhadap semangat kerja. Dengan signifikansi sebesar $0,000<$ 0,05 maka Ho ditolak dan Ha diterima. Artinya, ada hubungan signifikan antara mutasi, sistem pelatihan kerja dan semangat kerja. Adapun nilai Rsquare yang didapat adalah $0.850 \mathrm{hal}$ ini berarti bahwa variabel mutasi kerja (X1) dan pelatihan kerja (X2) mempengaruhi variabel semangat kerja (Z) sebesar $85 \%$, dan sisanya dipengaruhi oleh variabel lain-lain

2. Dalam analisa pengaruh mutasi kerja terhadap semangat kerja didapat 0.000 $<0.05$, sehingga $\mathrm{Ho}$ ditolak dan $\mathrm{Ha}$ diterima. Artinya ada pengaruh signifikan dari mutasi kerja terhadap semangat kerja. Adapun besar pengaruhnya yaitu 0,841 yang berarti mutasi kerja memberikan pengaruh sebesar $84,1 \%$ terhadap semangat kerja.

3. Dalam analisa pengaruh pelatihan kerja terhadap semangat kerja $0.008<$ 0.05 , sehingga $\mathrm{Ho}$ ditolak dan $\mathrm{Ha}$ diterima. Artinya ada pengaruh signifikan dari pelatihan kerja terhadap semangat kerja. Adapun besar pengaruhnya yaitu 0,130 yang berarti pelatihan kerja memberikan pengaruh sebesar $13,0 \%$ terhadap semangat kerja.

4. Dalam analisa hipotesis pengaruh penerapan mutasi kerja, pelatihan kerja terhadap semangat kerja didapatkan 
suatu hubungan kausal secara langsung dan persamaan regresi $\bar{Y}=0,744+$ $0,134 \mathrm{X} 1+0.185 \mathrm{X} 2+0,666 \mathrm{Z}$, artinya setiap satu pengaruh penerapan mutasi kerja, pelatihan kerja dan semangat kerja terhadap prestasi kerja akan berdampak sebesar nilai b diatas baik untuk X1, X2, dan Z terhadap prestasi kerja. Dengan signifikansi sebesar $0,000<0,05$ maka Ho ditolak dan Ha diterima. Artinya, ada hubungan signifikan antara mutasi kerja, pelatihan kerja dan semangat kerja terhadap prestasi kerja. Adapun nilai $\mathrm{R}$ - square yang didapat adalah 0.785hal ini berarti bahwa variabel mutasi kerja (X1),pelatihan kerja (X2)dan semangat kerja (Z) mempengaruhi variabel prestasi kerja (Y) sebesar 78,5 \%, dan sisanya dipengaruhi oleh variabel - variabel lain.

5. Dalam analisa pengaruh mutasi kerja terhadap prestasi kerja didapat 0.274 > 0.05 , sehingga Ho diterima dan $\mathrm{Ha}$ ditolak. Artinya tidak ada pengaruh signifikan dari mutasi kerja terhadap prestasi kerja. Adapun besar pengaruhnya yaitu 0,130 , yang berartimutasi kerja memberikan pengaruh sebesar $13,0 \%$ terhadap prestasi kerja.

6. Dalam analisa pengaruh pelatihan kerja terhadap prestasi kerja didapat $0,008<0.05$, sehingga Ho ditolak dan Ha diterima. Artinya ada pengaruh signifikan dari pelatihan kerja terhadap prestasi kerja.Adapun besar pengaruhnya yaitu 0,163 , yang berarti pelatihan kerja memberikan pengaruh sebesar 16,3\% terhadap prestasi kerja.

7. Dalam analisa pengaruh pelatihan kerja terhadap prestasi kerja didapat $0,000<0.05$, sehingga Ho ditolak dan Ha diterima. Artinya ada pengaruh signifikan dari semangat kerja terhadap prestasi kerja. Adapun besar pengaruhnya yaitu 0,665 , yang berarti mutasi kerja memberikan pengaruh sebesar $66,5 \%$ terhadap prestasi kerja.

\section{Saran}

Dari hasil penelitian yang dirumuskan dapat disarankan kepada kementrian agama kota Cilegon untuk dapat meningkatkan prestasi kerja karyawan melalui mutasi kerja dan pelatihan sehingga membentuk semangat kerja yang lebih baik. Untuk peneliti selanjutnya diharapkan agar dapat mengembangkan penelitian ini melalui penambahan variable dan perluasan objek penelitian. 


\section{DAFTAR PUSTAKA}

Danang, Sunyoto, (2012), Model Analisa jalur Riset Ekonomi, Penerbit : Yama Widya,Bandung

Hariwijaya, Drs. M \& Triton. (2011), Panduan skripsi dan tesis, oryza, Jakarta

Kartajaya, Hermawan. (2004). On Becoming A Customer - Centric Company: Gramedia Jakara.

Purwati, Astri, Ayu \& Satria, Hendri. (2018). Pengaruh Perekrutan, Motivasi, Dan Pelatihan Terhadap Kinerja Karyawan Pada CV. Skala Sport Pekanbaru. PROCURATIO (Jurnal Ilmiah Manajemen), 5(4): 418-429.

Riduwan. (2007). Skala Pengukuran Variabel-Variabel Penelitian, Penerbit Alfabeta, Bandung

Sarwono J. (2013). Statistik Multivariat Aplikasi untuk Riset Skripsi, Penerbit : ANDI Yogyakarta

Sedarmayanti. (2009). Manajemen Sumber Daya Manusia dan Produktifitas Kerja, Penerbit : Bumi aksMandar Maju, Bandung

Siagian, Sondang P. (2007). Manajemen Sumber Daya Manusia, Penerbit : Bumi aksara, Jakarta

Sofiah dan Syihabudhin, (2008). Manajemen Bisnis ritel, Penerbit : ANDI Yogyakarta

Sugiyono. (2008) "Metode Penelitian Bisnis", Penerbit : Alfabeta Bandung. 